\title{
Localization of International Hotel Brands in China
}

\author{
Yu Wang \\ Tourism Management Department, School of Management, Jinan University, Guangzhou, China \\ Email: 1551298355@qq.com
}

How to cite this paper: Wang, Y. (2016) Localization of International Hotel Brands in China. American Journal of Industriai and Business Management, 6, 942-946.

http://dx.doi.org/10.4236/ajibm.2016.69091

Received: July 22, 2016

Accepted: September 9, 2016

Published: September 12, 2016

Copyright $\odot 2016$ by author and Scientific Research Publishing Inc. This work is licensed under the Creative Commons Attribution International License (CC BY 4.0).

http://creativecommons.org/licenses/by/4.0/

\begin{abstract}
The hotel industry in China is in a stage of rapid development, and the development prospects of international hotel brands in Chinese market undoubtedly become the focus topic. The localization of international hotel brands is the inevitable trend of the development of international hotel. This paper expounds the reasons of international hotel brands localization and analyzes the localization strategies in China, mainly such as, talent localization, service localization, brand localization, and management localization.
\end{abstract}

\section{Keywords}

International Hotel Brands, Localization, Localization Strategy

\section{(c) (i) Open Access}

\section{Introduction}

With the rapid development of tourism and hospitality industry in China, lots of international hotel brands grasp the chance to expand in China [1]. Statistic shows that in the first quarter of 2014, the total number of star hotels reached 13,217 including 200 foreign brand hotels in China [2]. International hotel brands also present an increasing trend, especially those international high-end brand hotels such as InterContinental, Marriott, and Hilton [3]. It is not easy to survive in the fierce competition in China's hospitality industry for international hotel brands, as the domestic hotels have already occupied the market. Actually, international hotel brands in China always experienced great challenges, as its cultural difference, regional economic disparity, insufficient managerial talent, and even distinct consumer behavior can be obstacles for the success in the Chinese hospitality industry [4]. Learning how to localize is crucial for the development of international hotel brands in China. This paper will explain the reason why international hotel brands need localization, and how to realize localization. 


\section{Why International Hotel Brands Need Localization?}

\subsection{Obtain the Advantage of Effectively Utilizing Resources}

One of the important reasons for the operation of the hotel brands is to expand the influence and enhance the visibility of the hotel. However, localization can make the hotel brands utilize the local resources more effectively. Localization makes the hotel brands well adapt to Chinese culture and business environment, which is crucial for the hotel brands to use the local resource such as talent.

\subsection{Achieve Local Talent Supply}

Local talent supply is crucial for the operation and development of the international hotel brands. On the one hand, local talent supply can reduce the operating costs, and thus can maximize the hotel profits. On the other hand, local talent usually better understand the local characteristics and related conditions, which is conducive to the local development of the hotel brands.

\subsection{Easier Market Access}

Localization makes the product more affinity, and it is easier to understand the consumer psychology and requirements of the local customers, so that the host residents are psychologically more receptive. Hotel brands localization can improve the insight of the local market. It is easy to grasp the trend of the tourism market, which is conducive to the rapid access to the local market.

\subsection{Reduce the Impact of Cultural Differences}

Cultural differences have a significant impact on the development of a business company, especially for foreign hotel brands. If the hotel brands fail to overcome the cultural differences, it will be difficult to take root in the local culture or be able to develop. Hotel brands' localization is conducive to the full understanding of the local market, as well as to flexible grasp the relevant laws and regulations, so that the hotels can be better integrated into the local culture.

\section{Localization Strategy of International Hotel Brands}

Localization management of international hotel brands is mainly reflected in four aspects: talent localization, service localization, brand localization, and management localization.

\subsection{Talent Localization}

Talent localization refers to "the extent to which jobs originally held by expatriates are filled by local employees who are competent to perform the job" [3] [5]. "The talents localization process of international hotel brands has been an overwhelming trend" [6]. Localization of talents is conducive to establish intimacy relationship between international hotel brands and China. It also can overcome cultural and emotional differences in enterprise management and reduce enterprise management costs from expatriates. 
Besides, local talent usually better understand the local cultural characteristics, consumer psychology, consumer habits and emotional needs, so that they can more easily interact with consumers, government officials, and other stakeholders. There are several ways to achieve talent localization.

\subsubsection{Recruit Local Top Management Talent}

According to Wong \& Law, the localization of top management and technical talent is an important objective for many transnational corporations [7]. Top management talent localization is now a major concern for many international hotels operating in China. Senior hotel management personnel need long-term practice work experience. To cultivate a top management personnel needs a lot of time and energy, so the most effective and rapid way is the directly recruit local senior management personnel. And it is better to adopt a local recruiter, because the local people know more about their people's psychology and demand. It is also more likely to closer the relationship between the recruiters and applicants, so that can create a mutual trust and relaxed atmosphere. In such an interview atmosphere, the candidates can fully display their ability so that the recruiter can choose the most suitable local senior management personnel for the international hotel brands. At the same time, local recruitment supervisor is more familiar with the local recruitment information and recruitment site, which can greatly improve work efficiency and ensure accurate recruitment to the required local talent.

\subsubsection{Cultivate Local Talents}

A number of international hotel groups had experienced the bottleneck of the shortage of local top management talent in the process of operation, especially the shortage of local talent in the aspect of hotel construction, property management and hotel marketing. The current international hotel group began to focus on the training of local talent, and has begun to implement the talent pool plan.

\subsubsection{Abandon the Nationality and Racial Discrimination}

In the observation of the international hotel group, the discrimination against local talent is very serious. Take the housekeeping manager as an example, the salary and other welfare are different compared the local managers with the expatriate managers. This is the main reason why the local managers leave the international hotel brands. Local talents require equal treatment with the same post. Actually, give the same treatment to the local managers and the expatriate managers can reduce the operation costs, because the loss of local top management personnel for the hotel is definitely not worth the candle. Thus, treat the personnel equally and abandon the nationality and racial discrimination is beneficial for the economic and long-term development of the international hotel brands.

\subsection{Service Localization}

\subsubsection{Service Staff Localization}

Service staff is an indispensable factor in the process of service providing, because ser- 
vice relies on the interaction between the service staff and the customer. There is no satisfied customer without satisfied service staff. Personnel are the most valuable property of the hotel. The first task of service localization is to achieve service staff localization.

Service staff localization requires international hotel brands recruit as many local people as possible despite of a small number of local senior management. Adopt local labor can reduce the operation costs. Besides, local people are familiar with the local environment, culture, tradition, custom, and understand local people, they can better integrate the local culture into the business activities.

\subsubsection{Service Product Localization}

Any hotel has its core products, which must satisfy a certain market demand and has its own characteristics in the local market. International hotel brands need to provide different service product according to the customs, cultural differences, and the needs of Chinese customers. It will increase the competitiveness of the product and win the favor of Chinese customers.

\subsection{Brand Localization}

\subsubsection{Brand Naming Localization}

Named localization is a tool of brand communication for international hotel brands. Named localization can eliminate the consumer's psychological line of defense, and obtain a sense of psychological identity. Named localization is also easy for Chinese consumers to remember or identify. A number of international brands can quickly became popular in the Chinese market with its Chinese name.

\subsubsection{Brand Communication Localization}

The localization of brand communication mainly includes advertising localization, public relations localization, promotion methods localization and so on. Integrate Chinese elements into the website and entity of the international hotel brands is a good way of brand communication localization. For example, international hotel brands can hold promotional activities in the Chinese traditional festivals and holidays to enhance the sense of identity and unique visitor experience. To achieve the best results, we need pay attention to the organic integration of foreign brands hotels and local cultural atmosphere.

\subsubsection{Launch New Brand According to Local Conditions}

Launch new brand according to local conditions is very important. This will not only increase diversity of their own brand, but also can meet the consumer habits and aspirations of a specific areas and populations. The introduction of new brands in China which integrated into the Chinese culture is definitely conducive to the development of the brand itself.

\subsection{Management Localization}

\subsubsection{Owner Localization}

Owner localization refers to the investment company is a local company. Local compa- 
nies can better understand the local policies and culture, and survive in the fast developed society. The development of China's hotel industry is closely related to the development of Chinese economy, the development of real estate industry, and the development of financial investment industry. According to the development model of several major industries and related industries, $90 \%$ of the owners of international hotel brands investment companies are local companies. Local companies have its own advantages in the mobilization of the local resources.

\subsubsection{Management Talent Localization}

The localization of management talent includes three points. First, most industrial workers must be locals, besides, management backbone and technology backbone personnel should be local people as far as possible. Second, speed up the core management personnel to learn and master the local humane society and corporate culture. Third, pay attention to Chinese culture and customs when managing Chinese staff.

\section{Conclusion}

With the rapid development of hospitality industry in recent years, many international hotel brands expand their market to China. In order to obtain the advantage of effectively utilizing resources, achieve local talent supply, get access to the local market easier, and reduce the impact of cultural differences, international hotel brands take strategies to localize, such as talent localization, service localization, brand localization, and management localization.

\section{References}

[1] Wang, J.E. (2006) On the Development Strategy of International Hotel Management Groups in China. Tourism Tribune, 21, 70-76.

[2] CNTA (2014) Star Hotel Statistical Bulletin in the First Quarter of 2014. http://www.cnta.gov.cn/zwgk/lysj/201506/t20150610 18909.shtml

[3] Chan, D., Ye, T. and Xu, H. (2016) Localization of Senior Managers of International Luxury Hotels in China: The Current Situation and Influencing Factors. Journal of China Tourism Research, 12, 126-143. http://dx.doi.org/10.1080/19388160.2016.1160848

[4] Fayol-Song, L. (2011) Reasons behind Management Localization in MNCs in China. Asia Pacific Business Review, 17, 455-471. http://dx.doi.org/10.1080/13602381.2010.546642

[5] Selmer, J. (2010) Staff Localization and Organizational Characteristics: Western Business Operations in China. Asia Pacific Business Review, 10, 43-57. http://dx.doi.org/10.1080/13602380412331288800

[6] Liu, Y. (2004) Localization Strategy of Multinational Companies in China and Its Impact. Contemporary Asia-Pacific Studies, 6, 29-33.

[7] Wong, C. and Law, K.S. (1999) Managing Localization of Human Resources in the PRC: A Practical Model-Transferring Technology in Developing Countries. Journal of World Business, 34, 26-40. 
Submit or recommend next manuscript to SCIRP and we will provide best service for you:

Accepting pre-submission inquiries through Email, Facebook, LinkedIn, Twitter, etc. A wide selection of journals (inclusive of 9 subjects, more than 200 journals)

Providing 24-hour high-quality service

User-friendly online submission system

Fair and swift peer-review system

Efficient typesetting and proofreading procedure

Display of the result of downloads and visits, as well as the number of cited articles

Maximum dissemination of your research work

Submit your manuscript at: http://papersubmission.scirp.org/ 